\title{
Future Wild: Ecology, Sustainability, and Science Fiction
}

\author{
John Visvader' \\ College of the Atlantic, \\ Maine, United States
}

\section{Abstract}

It will be difficult to imagine a sustainable earth in the long-term future without realizing that we will have to increasingly interfere with natural earth systems in order to maintain ourselves and those things and creatures we value. Will we be able to speak of anything wild or even natural on such a managed planet? I argue in the affirmative, drawing on some concepts of nature of both the ancient Greeks and the Chinese. The essentialist concept of nature that depends on the absolute distinction between humans and nature is criticized, and a process view is suggested which sees nature as more than a collection of objects untouched by humans.

Keywords: concepts of nature, concepts of sustainability, concepts of wild, essentialism, science fiction

\section{Commentary}

When we talk about sustainability there is a problematic conservative factor that we are not often aware of. In this sense, to sustain means to hold on to, to keep something going - to keep something going in the same or similar way. We often get to conversations about this topic when we begin to fear that things are getting worse and about to get much worse, and we wonder how we can at least keep things as they are now or, at most, make things better. And when we think this way-either pessimistically, when we think it will be all that we can do to keep things from getting worse; or optimistically, when we think that we can make things better or even a lot better-we think long term, very long term. Sustainability riding off into the sunset.

The problematic factor concerning sustainability comes about in the following way, in two steps. First, we realize that what we want to sustain primarily is ourselves and all those sorts of things that we value. We don't want to freeze things, but we would like things to develop within a comfortable parenthesis, so to speak. Things can

1 Corresponding author: jvisvader@coa.edu 
develop freely and progress in various ways, but change can't be so large or drastic that the whole human enterprise is undercut. This is step one, the maintenance of the protective parenthesis. Step two comes about when we think about the longterm future. This is where the science fiction comes in.

The further into the future we look the more effort will appear necessary in attaining "sustainability," for we will have to deal with threats that do not arise primarily from the actions of human beings - though our own actions have and will often continue to add to our perils. In terms of geological time we are indeed a very young species of only a million or so years. During its four and a half billion years the earth has continually changed and various creatures that have inhabited its surface have come and gone. The longer the human species exists the more threats and disruptions it can expect from large-scale changes. The continents continue to move, other ice ages can be expected, and we now suspect the earth regularly receives large-scale collisions with astronomical objects.

If our technologies continue to develop as they have, we will increasingly be able to decide not only our own fate, but the fate of the planet and the other creatures that share it with us. In fact, we can look at these attempts we are making to develop a practical or applied human ecology as the first stages in the formation of the god-like art and science of planet management. In this sense, long-term sustainability means maintaining this particular kind of earth system into the indefinite future. This will involve either increased adaptability, or power to control large-scale earth systems, or both. Very long-term sustainability may require us to think of leaving the earth itself, or at least of transplanting life of various kinds in other places. Some have spoken of this possibility as the "greening of the universe."

I admit this is not a topic on our frontline agenda. Not many of us are worrying about what our possible long-term descendants will do when the sun uses up its supply of hydrogen four and a half billion years from now, to collapse and then expand to the orbit of the earth as it enters its helium cycle. Our problem is how to figure out how to begin living now in such a way that we can have future descendants to worry about such things. But this science fiction scenario about the future, though remote, raises some conceptual issues about the present, and it's those that I'm really after here.

For many of us, one of the things we'd like to take along with us into a sustainable future are the natural and wild systems that we still find in relative abundance. Many have argued for the intrinsic value of the wild and the natural. We would not like to lose a single species (look at the arguments for preserving the few remaining tubes of smallpox virus); some would even like to bring back vanished species via some sort of Jurassic Park technique. But continued, long-term sustainability means that these systems will have to live inside our parenthesis. Wild but not too wild, natural but not too natural. But can the earth, as a kind of futuristic Noah's ark, 
contain wild and natural systems? What would a wild system of the future, of even the very far distant future, look like-if we would even allow for the possibility? Of course, this depends upon what you want to call wild and natural.

There are some who have defined wild and natural in terms of the absence of human influence or effect. Some like Bill McKibben (1989) have argued that Nature itself is gone because there are effects of human processes everywhere on the globe. But this narrowness does not get us very far, for in this sense the natural and the wild have gone a long time ago. This sort of thing would also make it problematic to say such perfectly good things as describing a garden as going wild (because a garden, after all, is a human artifice), or even to speak of people behaving badly or living differently as "wild people."

Philosophy thrives in situations in which the normal categories of description break down when faced with novel or neglected situations. Is it male or female, plant or animal, living or dead, or - in our case - is it natural or unnatural, wild or manufactured or designed? Philosophers usually deal with these kinds of situations by giving recommendations for one usage or another, or by inventing a totally new term to cover the problematic situation. And here the arguments for the recommendation will resemble those in the law courts by citing certain precedents and examples that will have the force of analogy, or by emphasizing some salient features in the case at hand that may unlock the conceptual knots and guide us through the dilemma. I propose to do something like this in puzzling out the case as to whether or in what way a Noah's ark earth (or at least some parts of it) can have wild or natural areas. If we can make any progress with this, we may come to understand the wild and the natural in a slightly different way-one that might be more helpful for some purposes. For precedents, I'd like to call briefly on the ancient Greeks and Chinese.

The Greek word for nature is phusis, and if we can trust the etymology of someone like Heidegger it means "the emergent self-upraising, the self-unfolding that abides in itself" (Heidegger, 2000, p. 64) To translate this Heideggerese slightly, nature is not conceived as a group of objects with certain common properties-say, being untouched by humans - but as a process that things can undergo to a greater or lesser extent. Something comes forth like a flower that blooms, it unfolds, it "abides," it holds itself as what it is, it has integrity in the sense that it holds itself integral, then folds, withers or gets eaten. It's this aspect of the world that is dynamic, in flux, continuously emergent and constantly tumbling into new and different forms that is thought of as nature. As a process, nature is not alien to humans as we also manifest the same processes in different ways, at different times, and more or less. The Greek word poiesis, from which we derive the word poetry, is nature naturing (natura naturans) or unfolding clearly in humans. Humans manifest this when they are openly creative - that is, when they open themselves to a kind of inspirationit is something one can receive rather than do. 
Interestingly enough, the ancient Chinese of roughly the same period had very similar notions of nature as a process. The Chinese word for nature is $d z$ ran, which literally translated means "self-so," or that which is of itself so. It is sometimes translated as "spontaneous," something that comes forward by itself in its own way at its own time. Like the Greek concept, nature is something that is continuously self-emergent; it constantly discloses itself, holds itself in many forms that tumble into each other. Nature also permeated the human world in an important way. To incorporate into oneself this kind of spontaneous and creative action was one of the major efforts of Chinese spirituality and aesthetics. Many materials used in the arts invited or made use of the accidental or the recalcitrant. One learned to be spontaneously creative by working with these elements in one's environment. Rice paper was often prized for aesthetic purposes because it was highly absorptive and required artists to work quickly and freely, taking advantage of whatever unplanned accidents they were presented with. One became most creative when one became most natural.

Well, what do these examples tell us about nature, the natural or the wild that may be helpful to us? I think the first thing to notice is that in both cases nature and humans are not essentially opposed to each other, they are not defined as the negative of each other as north pole and south pole-they are not polar opposites. We, being over-civilized and super-urbanized, look desperately for something that is not us or our doing. We tend to think of nature as everything we are not, as our polar opposite. The Chinese were capable of making natural gardens. This sounds like an oxymoron to us.

Some Daoist monasteries had gardens that were continuously cultivated for hundreds of years but could not be recognized as such by an unenlightened or casual observer. In what sense could they be natural, in what sense wild? The Chinese were contextualists, they realized that there was no such thing as an isolated individualor in the lingo of Hobbes - an independent atomic individual. Everything is in relationship. Whether a tree is in a garden or in a forest, it unfolds in relation to the things around it. Since humans are not essentially opposed to nature, they could also enter into the web of relationships in which things unfold themselves. The key of course is to let things alone as much as possible without abandoning them completely, to encourage things to unfold themselves as much as possible. Things could be natural, and in a sense wild, even in a parenthesis, as long as the parenthesis was very wide and very gentle, as long as nature as process was a major factor.

This seems to me to capture one important part of the concept of wild-things are wild when they are left to do or develop on their own. But of course, nothing develops or acts completely on its own. Nothing is wild in any absolute or metaphysical sense; things are wild with respect to some aspect or some context that we find it important to contrast them with. Are there such things as wild horses? Well, sure- but of course all the wild horses that we used to round up for dog food 
were escaped horses that were carefully bred for centuries. "Wild" is one of those tricky contrast words that disguise themselves as substantives, and seem to name an absolute quality that a thing has similar to its hooves or tail or even genes. A horse in my stable can be wild in contrast to another horse in my stable that is more calm and cooperative. My unruly horse would not be considered wild when compared to the roaming dog-food horses, and of course these in turn would not be considered wild in comparison to a newly discovered herd of eohippus.

Let's now explore the question of what Future Wild would look like and whether it is even conceivable under the conditions I've sketched out. As long as we don't take wild to be some sort of intrinsic property, I don't see why we couldn't use the word as a way of contrasting features of things that we feel are important to us. Suppose in the far future we find that all creatures, including ourselves, have to be re-engineered genetically because of some terribly noxious conditions that arise on the earth, say from a collision with one of those mini black holes that are supposed to be roaming the universe. Can we call any of these creatures wild? The answer depends upon what contrasting features we are interested in. Some things will be wild when left to themselves as opposed to those things which are continually changed, controlled and influenced by us. As long as nature as process, in the Greek and Chinese sense, is allowed a large enough scope, things will develop "naturally" and by contrast be wild. Of course, these free-living genetically engineered creatures may not be considered wild in comparison to creatures that are not so engineered, but why make the origin such an important, almost metaphysical factor? Being unengineered alone doesn't make them wild. Suppose we kept the few remaining originals in a huge air tank zoo, would they be wilder than their modified descendants left on their own to roam without interference? These might be revered because they are rare but not because they are wild.

So of course I think that we can talk of wild places and wild things in a future Noah's ark world, but the key here has to be the same thing that applies in a Chinese garden; leave the things alone as much as possible, keep the parenthesis as broad and gentle as possible. But don't the unengineered creatures have more intrinsic worth than those that are not? In answering this I come to the most contentious part of this little paper. These "unaltered creatures" will have more worth to the degree that we hold an essentialist view of the natural and the wild. They will have more worth to the degree that we hold an absolute distinction between humans and nature; humans themselves, according to the essentialist view, must in some sense be held to be artificial, and everything they do must be seen to be unnatural. Why is a beaver dam natural but a human dam not-even though the beaver dam might be much bigger in a particular case and more environmentally significant? Such an absolute dichotomy is itself artificial and has always been difficult to defend conceptually, and at present is becoming difficult to maintain practically. (Some have suggested, 
with some insight, that this abyss between humans and nature has been fostered by the humanist tradition's incorporation of Platonic Christianity, in its attempt to ward off the exaggerations of naturalistic reductionism.)

We can easily imagine a time in the not-too-distant future in which the use of prosthetics will become the rule, and a dispute arises between the 20 percenters (those who have $20 \%$ or less of artificial organs) and the 50 percenters as to who is artificial and who is natural. The essentialist will claim that neither group is natural; only one without any artificial organs is natural. But would such a "natural" person be able to wear glasses, clothes, have fillings in their teeth, or use tools? The Greek philosopher Diogenes was famous for his cynicism—walking around in daylight with a lighted lantern looking for an honest man-but his cynicism also led him to reject the artificiality of human life and he tried to live naturally. He wore no clothes, lived in a cast-off wine jar (they were pretty big in those days) and tried to refrain from using human speech. Most feel that his concept of natural was a little artificial and had gone too far, but here was an essentialist trying, paradoxically, to be natural. The paradox arises from the absolute dichotomy between humans and nature, so that even someone who tried as hard as Diogenes to be natural was doomed to be artificial.

This distinction-between the natural and the artificial, the wild and the tame (or whatever its counterpart is) — though it may have immense practical value in underlining contrasts we feel it important to make, when taken philosophically in an essentialist sense offers us little in the way of guidance as to what is valuable and what we should cherish. Is a test-tube baby worth less than one who was conceived in the usual manner? And what is the usual manner? Can we plan our children without decreasing their value? Few think that cloning is something that we ought to do, but clones would not be much different than identical twins. Some fertility drugs seem to stimulate multiple births of identicals_are any of these "copies" worth less than "originals"? I think the problem of clones has to do with the purpose which may bring them about. We don't want humans treated instrumentally as organ donors; we also feel that such produced humans will be things controlled in some way and therefore less human. In a world in which technology will give us an increasing ability to control our circumstances, and at a time in which technology may be necessary to maintain sustainability, we will find that origin will become less important in our valuation of things. We don't value programmed humans or things whose details and actions are fully predicted and controlled or altered merely for our pleasures or purposes. In the Chinese sense, we value things that are self-sos, things that can determine in one way or another their own circumstances or fate. We all live within parentheses of one kind or another, but we also respect and strive for an openness and freedom within our circumstances. 
As for Future Wild, why not? All we have to do is to make sure to learn to leave things alone, the more the better, within a gentle parenthesis. Nothing is wild in any absolute sense, but things can remain wild in a sense that is important both to them and to us.

\section{References}

Heidegger, M. (2000). Introduction to metaphysics (G. Fried \& R. Polt, Trans.). Yale University Press. (Original work published 1953).

McKibben, B. (1989). The end of nature. Random House. 
This text is taken from Human Ecology Review, Volume 25, Number 2, 2019, published by ANU Press, The Australian National University, Canberra, Australia. doi.org/10.22459/HER.25.02.2019.02 